\title{
Tingkat Pendapatan Orang Tua Menjadi Faktor Utama Pernikahan Dini Pada Remaja Putri
}

\author{
Andri Nur Sholihah ${ }^{1 *}$, Nurma Yunita ${ }^{2}$ \\ 1,2 Universitas Aisyiyah Yogyakarta, Indonesia
}

\section{A B S T R A C T}

The Early marriage is a topic that is seldom discussed anymore, yet despite the passage of time, this practice has not fully vanished. The goal of this research is to learn more about the factors that impact the rate of early marriage among young women. A descriptive correlation method with a cross sectional approach is used in the study design. At the Office of Religious Affairs (KUA) Gamping District, Sleman Regency, there are 34 young ladies under the age of 20 who are married. There were 34 persons in this study's sample. Total sampling is the sampling method used. A questionnaire is used as a research tool. ChiSquare is a statistical test. Parental income (0.043), respondent's education level (0.031), and respondent's attitude all have $p$ values less than 0.05 and impact early marriage.

Keywords : early marriage; young women

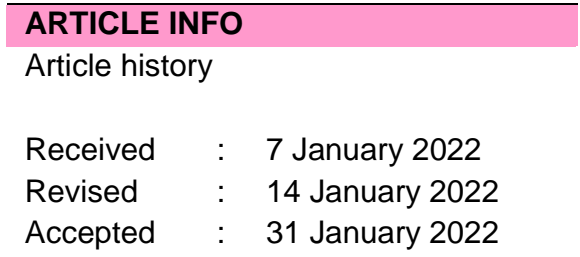

DOI

DOI: 10.31983/micajo.v3i1.8188

\begin{tabular}{lll}
\multicolumn{2}{l}{ CORRESPONDING AUTHOR } \\
Name & $:$ & Andri Nur Sholihah \\
Email & $:$ & andrisholihah@unisa \\
& yogya.ac.id \\
Telp & $:$ & 085725470081 \\
Address & $:$ & Kedungrejo Rt 37, \\
& & Sidodadi, Masaran \\
& Sragen, Kode pos \\
& 57282
\end{tabular}

ORIGINAL RESEARCH

\section{Pendahuluan}

Pernikahan dini bagi Sebagian kalangan merupakan hal yang tak biasa dibicarakan secera umum, namun hal ini menjadi suatu fenomena saat pernikahan dini mulai kembali menjadi tren, mengingat dampak ini yang ditimbulkan dari pernikahan dini pada remaja ada 2 yaitu dampak psikologis dan dampak fisik. Dampak psikologis yang dapat terjadi yaitu depresi berat, keadaan ekonomi, dan konflik yang berujung pada perceraian dikarenakan kestabilan emosi yang mudah berubah-ubah. (Rohan \& Siyoto, 2013)

Dampak fisik yang dapat terjadi pada remaja yang menikah dini yaitu kesehatan organ reproduksi yang belum mature dapat terganggu yang bisa berakibat pada resiko terjadi kanker serviks dan resiko tinggi pada saat kehamilan dan persalinan yang bisa menyebabkan kematian. Perempuan usia 15-19 tahun memiliki kemungkinan dua kali lebih besar meninggal saat melahirkan ketimbang yang berusia 20-25 tahun, sedangkan usia di bawah 15 tahun kemungkinan meninggal bisa lima kali. Ada banyak akibat negatif dari pernikahan dini salah satunya apabila seorang anak hamil pada usia emas (sampai dengan 19 tahun), anak tidak akan mendapatkan asupan gizi yang cukup untuk tumbuh kembang karena harus berbagi dengan bayi di dalam kandungan.(Koes Irianto, 2015) 
Badan Kependudukan dan Keluarga Berencana Nasional (BKKBN) menyebutkan kanker leher rahim menduduki peringkat pertama kanker yang menyerang perempuan indonesia, angka kejadian saat ini 23\% diantara kanker rahimkarena banyak perempuan yang menikah di usia dini. Di DKI Yogyakarta sendiri tercatat 269 perempuan yamg dicurigai mengalami kanker servik. (Dinkes Provinsi DIY, 2016)

Menurut World Health Organization (WHO) (Wikasari. D. G, 2016) menyebutkan bahwa sebanyak 16 juta kelahiran terjadi pada ibu yang berusia 15-19 tahun atau 11\% dari seluruh kelahiran di dunia yang mayoritas (95\%) terjadi di negara sedang berkembang. Indonesia termasuk Negara dengan persentase pernikahan usia muda tinggi di dunia yaitu ranking 27 dan merupakan tertinggi kedua di Association of South East Asia Nations (ASEAN) setelah Kamboja. Pada tahun 2012 di Indonesia, angka perempuan menikah usia 10-14 sebesar $4,2 \%$, sementara perempuan menikah usia 15-19 tahun sebesar $41,8 \%$. (Nurjanah et al., 2013)

Angka pernikahan di bawah umur di Daerah Istimewa Yogyakarta terbilang cukup tinggi. Berdasarkan data dari kantor wilayah Kementerian Agama Daerah Istimewa Yogyakarta pada tahun 2016 sampai 2017 tercatat di Sleman yang melakukan pernikahan dibawah umur < 16 sebanyak 70 orang, Kulon Progo 28 orang, Bantul 39 orang, Gunung Kidul 67 orang dan kota Yogyakarta 48 orang.

Sesuai dengan tujuan kelima poin tiga Sustainable Development Goals (SDGs) 2015 adalah mengikat komitmen semua negara untuk menghapus semua praktik berbahaya terhadap perempuan dan anak, termasuk perkawinan usia anak. Peran bidan sangat penting dalam pernikahan dini pada remaja terutama kepada orang tua yaitu dengan memberikan konsling kepada orang tua tentang dampak dan resiko yang ditimbulkan jika anak remaja putri mereka menikah diusia dini sehingga orang tua tahu bahwa pernikahan anak dibawah umur adalah sesuatu yang harus dihindari, dan melakukan pendekatan kepada remaja dengan memberikan penyuluhan tentang dampak dan akibat pergaulan bebas serta resiko jika menikah diusia dini. (Rohman, 2017).

\section{Metode}

Penelitian ini menggunakan desain penelitian deskriptif kolerasi dengan menggunakan pendekatan cross sectional dimana variabel independen (pengetahuan responden, pendidikan, penghasilan orang tua dan sikap seks pranikah) serta variabel dependen (pernikahan dini) yang diukur pada waktu yang bersamaan saat penelitian.

Penelitian dilaksanakan di wilayah kecamatan gamping yang menikah di Kantor Urusan Agama Gamping 2017. Populasi dalam penelitian ini adalah remaja putri yang sudah menikah dan bertempat tinggal di Kecamatan Gamping Kabupaten Sleman Sebanyak 36 orang. Teknik pengambilan sampel total sampling yaitu keseluruhan dari populasi yakni 36 orang sampel. Kriteria Sampel dalam penelitian ini terdiri : Kriteria Inklusi, wanita yang melakukan pernikahan usia dini (usia menikah < 20 tahun di kecamatan gamping kabupaten sleman tahun 2017. Kriteria Ekslusi yaitu responden yang sudah pindah di luar Kecamatan Gamping dan wanita yang tiak terdaftar di catatan pernikahan di Kantor Urusan Agama (KUA) Kecamatan Gamping sehingga tidak bisa dijadikan sampel. Pengumpulan data menggunakan kuesioner. Analisa data pada penelitian ini terdiri dari Univariat dan Bivariat, dengan uji statistik menggunakan Chi- Square. 


\section{Hasil dan Pembahasan}

Analisa yang dilakukan terhadap tiap variabel untuk mengungkap korelasi atau hubungan antara variabel dependen (pernikahan dini) yang satu dengan variabel independen (penghasilan orang tua, pendidikan responden, pengetahuan, dan sikap seks pranikah) yang disajikan dalam bentuk tabel distribusi frekuensi.

Tabel 1. Hubungan penghasilan orang tua dengan pernikahan usia dini

\begin{tabular}{|c|c|c|c|c|c|c|c|c|}
\hline \multirow{3}{*}{ Penghasilan } & \multicolumn{4}{|c|}{ Pernikahan Usia Dini } & \multirow{2}{*}{\multicolumn{2}{|c|}{ Total }} & \multirow{3}{*}{ P-value } & \multirow{3}{*}{$\begin{array}{c}\text { Contingency } \\
\text { coefficient }\end{array}$} \\
\hline & \multicolumn{2}{|c|}{ 14-16 tahun } & \multicolumn{2}{|c|}{ 17-19 tahun } & & & & \\
\hline & $f$ & $\%$ & $f$ & $\%$ & $f$ & $\%$ & & \\
\hline Tinggi & 0 & 0 & 14 & 41 & 14 & 41 & 0,043 & 0,328 \\
\hline Rendah & 5 & 15 & 15 & 44 & 20 & 59 & & \\
\hline Total & 5 & 15 & 29 & 85 & 34 & 100 & & \\
\hline
\end{tabular}

Tabel 2. Hubungan antara pendidikan responden dengan pernikahan usia dini

\begin{tabular}{|c|c|c|c|c|c|c|c|c|}
\hline \multirow{3}{*}{ Pendidikan } & \multicolumn{4}{|c|}{ Pernikahan Usia Dini } & \multirow{2}{*}{\multicolumn{2}{|c|}{ Total }} & \multirow{3}{*}{$P$-value } & \multirow{3}{*}{$\begin{array}{c}\text { Contingency } \\
\text { coefficient }\end{array}$} \\
\hline & \multicolumn{2}{|c|}{ 14-16 tahun } & \multicolumn{2}{|c|}{ 17-19 tahun } & & & & \\
\hline & $f$ & $\%$ & $f$ & $\%$ & $f$ & $\%$ & & \\
\hline Dasar & 5 & 15 & 14 & 41 & 19 & 56 & 0,031 & 0,346 \\
\hline Menengah & 0 & 0 & 15 & 44 & 15 & 44 & & \\
\hline Tinggi & 0 & 0 & 0 & 0 & 0 & 0 & & \\
\hline Total & 5 & 15 & 29 & 85 & 34 & 100 & & \\
\hline
\end{tabular}

Tabel 3. Hubungan antara pengetahuan responden dengan pernikahan usia dini

\begin{tabular}{|c|c|c|c|c|c|c|c|c|}
\hline \multirow{3}{*}{ Pengetahuan } & \multicolumn{4}{|c|}{ Pernikahan Usia Dini } & \multirow{2}{*}{\multicolumn{2}{|c|}{ Total }} & \multirow{3}{*}{ P-value } & \multirow{3}{*}{$\begin{array}{c}\text { Contingency } \\
\text { coefficient }\end{array}$} \\
\hline & \multicolumn{2}{|c|}{ 14-16 tahun } & \multicolumn{2}{|c|}{ 17-19 tahun } & & & & \\
\hline & $f$ & $\%$ & $f$ & $\%$ & $f$ & $\%$ & & \\
\hline Baik & 1 & 3 & 13 & 38 & 14 & 41 & 0,008 & 0,469 \\
\hline Cukup & 3 & 9 & 2 & 6 & 5 & 15 & & \\
\hline Kurang & 1 & 3 & 14 & 41 & 15 & 44 & & \\
\hline Total & 5 & 15 & 29 & 85 & 34 & 100 & & \\
\hline
\end{tabular}

Tabel 4. Hubungan antara sikap Seks Pranikah responden dengan pernikahan usia dini

\begin{tabular}{|c|c|c|c|c|c|c|c|c|}
\hline \multirow{3}{*}{ Sikap Seks Pranikah } & \multicolumn{4}{|c|}{ Pernikahan Usia Dini } & \multirow{2}{*}{\multicolumn{2}{|c|}{ Total }} & \multirow{3}{*}{ P-value } & \multirow{3}{*}{$\begin{array}{c}\text { Contingency } \\
\text { coefficient }\end{array}$} \\
\hline & \multicolumn{2}{|c|}{ 14-16 tahun } & \multicolumn{2}{|c|}{ 17-19 tahun } & & & & \\
\hline & $f$ & $\%$ & $f$ & $\%$ & $f$ & $\%$ & & \\
\hline Baik & 0 & 0 & 14 & 41 & 14 & 41 & 0,043 & 0,328 \\
\hline Kurang & 5 & 15 & 15 & 44 & 20 & 59 & & \\
\hline Total & 5 & 15 & 29 & 85 & 34 & 100 & & \\
\hline
\end{tabular}

a. Distribusi frekuensi penghasilan orang tua, pendidikan responden, pengetahuan responden dan sikap seks pranikah responden.

Karakteristik responden berdasarkan pendapatan menunjukkan bahwa yang memiliki pendapatan responden rendah sebesar 20 responden (59\%). Penghasilan adalah pendapatan yang didapat oleh seseorang dalam sebulan yang kemudian 
dibandingkan berdasarkan jumlah anggota keluarga seorang akan memanfaatkan pelayanan kesehatan berdasarkan jumlah penghasilan yang didapat olehnya.

Hasil penelitian menunjukkan bahwa pendapatan orang tua responden dapat dikatakan rendah karena mayoritas memiliki penghasilan dibawah Rp. 1.574.550,-. Hal ini akan menjadi pertimbangan orang tua dari sisi ekonomi akan meringankan beban ekonomi keluarga, ketika memiliki anak yang siap dengan pernikahan dini tanpa melihat usia anak tersebut.Hasil temuan ini dikuatkan dalam penelitian (Sari \& Asnindari, 2016) sebab-sebab utama dari pernikahan dini bahwa salah satu penyebab pernikahan usia dini yaitu masalah ekonomi keluarga.

Karakteristik responden berdasarkan pendidikan responden menunjukkan bahwa sebagian besar pendidikan responden memiliki latar belakang pendidikan dasar sebanyak 19 responden (56\%). Jenjang pendidikan adalah tahapan pendidikan yang ditetapkan berdasarkan tingkat perkembangan peserta didik, tujuan yang akan dicapai dan kemampuan yang dikembangkan. menurut UU nomor 9 tahun 2009, jenjang pendidikan di Indonesia terdiri atas pendidikan dasar, pendidikan menengah dan pendidikan tinggi. Pendidikan responden akan memberikan konstribusi pada pengetahuan tentang kesehatan dirinya sendiri. Tingkat pendidikan akan memberikan pemahaman secara matang kepada individu untuk memilih mutuskan suatu hal. Individu tersebut tidak menginginkan jika hal yang buruk yang telah diambil olehnya.Hal ini dikuatkan dalam hasil penelitian (Wulanuari et al., 2017) Faktor-faktor yang berhubungan dengan pernikahan dini bahwa salah satu penyebabnya yaitu pendidikan, Pendidikan dasar atau menengah lebih cenderung dinikah oleh orang tuanya karena yang berpendidikan rendah tingkat produktif

Hasil Penelitian tentang pengetahuan menunjukkan bahwa sebagian besar responden memiliki pengetahuan kurang sebanyak 19 responden $(60 \%)$. Hasil penelitian ini menunjukkan pengetahuan yang dimiliki responden mayoritas kurang. Kurangnya pengetahuan akan berakibat pada buruknya perkawinan diusia muda karena masih minim dengan kesiapan mental, materi, dan psikologi yang aspek tersebut didapatkan melalui pengetahuan.

Hal ini dikuatkan dalam penelitian (Sari \& Asnindari, 2016) sebab- sebab utama dari pernikahan dini bahwa salah satu penyebab pernikahan usia dini yaitu pengetahuan. Kurangnya pengetahuan tentang akibat buruknya perkawinan yang terlalu muda baik bagi remaja maupun keturunan yang dihasilkan.

Hasil penelitian tentang sikap seks pranikah menunjukkan bahwa sebagian besar responden sikap seks pranikah kurang sebanyak 20 responden (59\%). Sikap seksual adalah respon seksual yang diberikan oleh seseorang setelah melihat, mendengar atau membaca informasi serta pemberitaan, gambar-gambar yang berbau porno daam suatu wujud orientasi atau kecenderungan dalam bertindak. Sikap seks pranikah dalam penelitian ini masuk dalam kategori kurang, artinya sikap seksual responden ada penyimpangan. Sikap menyimpang yang terjadi karena kurangnya kesadaran remaja akan kehidupan mereka kedepan. Hal ini dapat terjadi karena terbatasnya perhatian orang tua, pendidikan orang tua, dan aspek pengetahuan responden.

\section{b. Penghasilan orang tua berhubungan dengan pernikahan usia dini.}

Hasil penelitian pada hubungan penghasilan orang tua dengan pernikahan usia dini paling banyak responden memiliki kecenderungan orang tua berpenghasilan rendah menyebabkan pernikahan usia dini di usia 17-19 Tahun berjumlah 15 (44\%) responden. Berdasarkan hasil penelitian ini diperoleh harga koefisien hubungan penghasilan orang 
tua dengan pernikahan usia dini nilai $p$-value sebesar $0,043<0,05$. Dari hasil tersebut dapat disimpulkan bahwa ada hubungan penghasilan orang tua dengan pernikahan usia dini. Adanya hubungan antara penghasilan orang tua dengan pernikahan usia dini dapat dipengaruhi faktor masalah ekonomi.

Dalam hasil penelitian ini dapat dikatakan bahwa pernikahan usia dini memiliki hubungan dengan penghasilan orang tua. Hasil penelitian ini menyatakan bahwa salah satu faktor pernikahan usia dini adalah untuk mengurangi beban keluarga. Para orang tua menikahkan anaknya pada usia muda menganggap bahwa menikahkan anaknya di usia muda, maka beban ekonomi akan berkurang satu. Bahkan orang tua berharap jika anaknya sudah menikah maka akan membantu kehidupan orang tuanya. (Desiyanti, 2015)

\section{c. Pendidikan responden berhubungan dengan pernikahan usia dini.}

Hasil penelitian pada hubungan penghasilan orang tua dengan pernikahan usia dini paling banyak responden memiliki kecenderungan orang tua dengan latar pendidikan menengah berjumlah 15 (44\%) responden. Dengan nilai $p$-value sebesar 0,031<0,05. Dari hasil tersebut dapat disimpulkan bahwa terdapat hubungan antara pendidikan responden dengan pernikahan usia dini.

Tingkat pendidikan akan memberikan pemahaman secara matang kepada individu untuk memilih mutuskan suatu hal. Individu tersebut tidak menginginkan jika hal yang buruk yang telah diambil olehnya.

Hal ini dikuatkan dalam penelitian (Sari \& Asnindari, 2016) sebab- sebab utama dari pernikahan dini bahwa salah satu penyebab pernikahan usia dini yaitu pendidikan, Pendidikan dasar atau menengah lebih cenderung dinikah oleh orang tuanya karena yang berpendidikan rendah tingkat produktif

\section{d. Pengetahuan berhubungan dengan pernikahan usia dini.}

Hasil penelitian pada hubungan antara pengetahuan responden dengan pernikahan usia dini paling banyak responden memiliki kecenderungan berpengetahuan kurang pada pernikahan usia dini 17-19 Tahun berjumlah 14 (41\%) responden. Berdasarkan hasil penelitian ini diperoleh harga koefisien hubungan memiliki nilai $p$-value sebesar $0,008<0,05$. Dari hasil tersebut dapat disimpulkan bahwa ada hubungan antara antara pengetahuan responden dengan pernikahan usia dini.

Hasil penelitian ini menyatakan bahwa pengetahuan responden memiliki hubungan dengan kejadian pernikahan usia dini. Hal ini dapat terjadi karena pengetahuan responden masih kurang. Akibat minimnya pengetahuan responden tentang pernikahan usia dini akan akan menjadi faktor utama dalam kejadian pernikahan usia dini.

Pengetahuan atau kognitif merupakan domain yang sangat penting dalam membentuk tindakan seseorang. Dalam teori perilaku tindakan yang berkaitan dengan kesehatan hi oleh tiga faktor yaitu: Presdisposing factor, enabling faktor, dan reirforshing faktor. Hasil penelitian tersebut membuktikan bahwa pengetahuan seseorang sangat berpengaruh terhadap terjadinya pernikahan usia dini.

Dalam hal ini pengetahuan responden akan mempengaruhi responden untuk memutuskan melakukan pernikahan usia dini.

\section{e. Sikap seks pranikah responden berhubungan dengan pernikahan usia dini.}

Hasil penelitian pada hubungan antara sikap seks pranikah responden dengan pernikahan usia dini paling banyak responden memiliki kecenderungan sikap kurang memiliki pernikahan usia dini 17-19 Tahun berjumlah 15 (44\%) responden. Penguji hipotesis dilakukan dengan menggunakan analisis korelasi chi Square. Berdasarkan hasil 
penelitian ini diperoleh harga koefisien sikap seks pranikah responden dengan pernikahan usia dini dengan nilai $p$-value sebesar $0,043<0,05$. Dari hasil tersebut dapat disimpulkan bahwa ada hubungan sikap seks pranikah responden dengan pernikahan usia dini.

Menurut (Notoatmodjo, 2009) sikap merupakan reaksi ataupun respon seseorang yang masih tertutup terhadap suatu stimulus atau objek. Sikap secara nyata menunjukkan konotasi adanya kesesuaian reaksi terhadap stimulus sosial, sikap mengandung unsur menerima, merespon, menghargai, dan bertanggung jawab. Hal ini dikarenakan sikap responden terbentuk oleh lingkungan tempat tinggal dimana sekitar tempat tinggal rsponden banyak yang seusia responden yang seusia responden yang melakukan pernikahan usia dini.

\section{Simpulan}

Berdasarkan hasil penelitian ini dapat disimpulkan bahwa pendapatan orang tua menjadi faktor utama dalam pernikahan dini bagi remaja putri.

\section{Daftar Pustaka}

Desiyanti, I. W. (2015). Faktor-Faktor yang Berhubungan Terhadap Pernikahan Dini Pada Pasangan Usia Subur di Kecamatan Mapanget Kota Manado Factors Associated With Early Mariage In Couples Of Childbearing Age At Kecamatan Mapanget Manado City. Jikmu, 5(2), 270-280.

Dinkes Provinsi DIY. (2016). Profil Kesehatan DIY Tahun 2016.

Koes Irianto. (2015). Memahami Berbagai Macam Penyakit. Jakarta: Alfabeta.

Notoatmodjo, Soekidjo. (2009). Pengembangan Sumber Daya Manusia. Jakarta: Rineka Cipta.

Nurjanah, R., Estiwidani, D., \& Purnamaningrum, Y. E. (2013). Penyuluhan dan Pengetahuan Tentang Pernikahan Usia Muda. Jurnal Kesehatan.

Rohan, H. H., \& Siyoto, Sandu. (2013). Buku Ajar Kesehatan Reproduksi. Yogyakarta: Nuha Medika.

Rohman, H. (2017). Batas Usia Ideal Pernikahan Perspektif Maqasid Shariah. Journal of Islamic Studies and Humanities, 1(1), 67. https://doi.org/10.21580/jish.11.1374

Sari, L. Y., \& Asnindari, L. N. (2016). Faktor-Faktor Yang Berhubungan Dengan Kejadian Unintended Pregnancy Pada Remaja. Jurnal Kebidanan Dan Keperawatan, 12(2), 163172.

Wikasari. D. G. (2016). Hubungan Peran Orang Tua dengan Persepsi Remaja tentang Pernikahan Usia Dini di Sma N 1 Banguntapan Bantul. Fakultas IImu Kesehatan Universitas 'Aisyiyah Yogyakarta.

Wulanuari, K. A., Anggraini, A. N., \& Suparman, S. (2017). Faktor-Faktor yang Berhubungan dengan Pernikahan Dini pada Wanita. Jurnal Ners Dan Kebidanan Indonesia, 5(1), 68. https://doi.org/10.21927/jnki.2017.5(1).68-75 